\title{
A FOGYASZTÓI ADÁSVÉTEL EGYES KÉRDÉSEINEK SZABÁlYOZÁsa ÉS JOGGYAKORLATa SZLOVÁKIÁBAN ${ }^{\mathrm{I}}$
}

\author{
Peter Mészáros
}

\author{
Debreceni Jogi Mühely, 2020. ÉVi (XVII. ÉVfolyam) I-2. \\ DOI I0.24I69/DJM/2020/I-2/5
}

\section{A szabályozás kialakulása és hatályos állapota}

A fogyasztási cikkek értékesítésről szóló irányelvet ${ }^{2}$ (továbbiakban: 1999/44/EK irányelv) a Tt. ${ }^{3}$ 150/2004. számú törvény ${ }^{4}$ ültette át a szlovák jogba, elsődlegesen a Tt. 40/1964. számú, Polgári Törvénykönyvről szóló törvény (a továbbiakban: SzPtk.), és részben a Tt. 634/1992. számú, fogyasztóvédelemről szóló törvény módosításával. ${ }^{5}$ A Tt. 634/1992 sz. fogyasztóvédelmi törvényt és a Szlovák Nemzeti Tanács 372/1990. számú határozatát később hatályon kívül helyezte az új, Tt. 250/2007 sz. fogyasztóvédelmi törvény, (jelen tanulmány a továbbiakban az új fogyasztóvédelmi törvényre utal mint “SzFvt.”). Általánosságban elmondható, hogy a fogyasztási cikkek adásvételére vonatkozó szerződéseket az SzPtk. szabályozza, az SzFvt. pedig részletesebb szabályokat fogalmaz meg a fogyasztási cikkekre vonatkozó jótállásból eredő jogok érvényesítésére.

1 A tanulmány megírása és megjelentetése az Igazságügyi Minisztérium jogászképzés színvonalának emelését célzó programjai keretében valósult meg.

2 Az Európai Parlament és a Tanács 1999/44/EK irányelve (1999. május 25.) a fogyasztási cikkek adásvételének és a kapcsolódó jótállásnak egyes vonatkozásairól, HL L 171., 1999.7.7., 12-16.

3 A szlovák jogban a törvényeket hivatalosan is törvénytárba (továbbiakban: Tt.) sorolják, amelyre a törény neve is utal, hasonlóan a régi (1945 előtti) magyar jogban egykor használatos törvénycikkhez.

4 Tt. 150/2004. sz. törvény a Polgári Törvénykönyvről szóló Tt. 40/1964. sz. törvény módosításáról. E törvénynek nemcsak az 1999/44/EK irányelv átültetése volt a célja, hanem a Tanács 1993. április 5-i, fogyasztókkal kötött szerződésekben alkalmazott tisztességtelen feltételekről szóló 93/13/EGK irányelvének és a Parlament és a Tanács 1994. október 26-i, az ingatlanok időben megosztott használati jogának megszerzésére irányuló szerződések egyes szempontjai vonatkozásában a fogyasztók védelméről szóló 94/47/EK irányelvének átültetése is.

5 Bővebben: R. Dobrovodský: Legislative Zersplitterung des slowakischen Verbraucherrechts. In: M. Novotná (ed.): Zásady európskeho súkromného práva v aplikačnej praxi. Spotrebitellský kódex: áno či nie? Leges, Praha, 2018, 111-139.; R. Dobrovodský: Der Einfluss des europäischen Verbraucherrechts auf das slowakische Schuldrecht. In: W. Rudolf (ed.): Der Einfluss des EU-Rechts in den Jahren 2007-2017 auf die Privatrechtsordnungen der CEE-Staaten. MANZ Verlag, Wien, 2019. 89-100.; R. Dobrovodský: Rechtsschutz des Verbrauchers (Eigentümers) vor Folgen der Liberalisierungs- und Deregulierungsschritte. Erfahrungsbericht aus der Slowakei. In: T. Zarandia et al (eds.): Eigentum und Rechtssicherheit: Wandel des Eigentumsbegriffs. Staatliche Ivane-Javakhishvili-Universität, Tbilisi, 2016. 
Az 1999/44/EK irányelv SzPtk.-ba történő átültetése általánosságban az adásvételi szerződés hatályán kívül eső egyedi fogyasztói adásvételi szerződések szabályozásának létrehozását jelentette, és elsősorban magának a fogyasztói jogi szabályozásnak a létrehozását (mivel ezzel együtt két másik irányelv is átültetésre került), amely az Európai Unióhoz való csatlakozással összefüggő tagállami kötelezettségek részét képezte. Az irányelv átültetése a nyilvánosság számára elsősorban a 2 éves kötelező jótállás megállapítása miatt vált ismertté, amely addig Szlovákiában hat hónap volt. ${ }^{6}$

Az 1999/44/EK irányelv átültetése (valamint két további irányelv átültetése a Tt. 150/2004. törvénnyel) egyúttal az ún. "harmadik jogág” létrehozásának tekintendő (a polgári és kereskedelmi mellett), és jogi bizonytalanságot teremtett a következő (legalább) tíz évre, abban a tekintetben, hogy a fogyasztók szerződési szabadsága alárendelhető-e a kereskedelmi vagy polgári jogi szabályozásnak. Ezt a kérdést elöször a nemzeti jogalkotó döntötte el a Tt. 102/2014. sz. törvénnyel, amelyben elöírta, hogy minden olyan jogviszonyra, amelyben fogyasztó vesz részt, minden esetben az SzPtk. kedvezőbb rendelkezéseit kell alkalmazni, még akkor is, ha a kereskedelmi jog szabályai egyébként másként rendelkeznek.7 Ezzel összefüggésben a bírói gyakorlat nem volt következetes, különösen a hivatkozott módosítás előtt kialakult jogviszonyok vonatkozásában. Végül a kérdést a Szlovák Legfelsőbb Bíróság döntötte el, ${ }^{8}$ amely úgy ítélte meg, hogy a hivatkozott rendelkezést a hatályba lépése előtt létesített jogviszonyokra is alkalmazni kell, visszamenőlegesen. E döntéssel összefüggésben alkotmányossági aggályok merültek fel az Alkotmánybíróság előtt, ${ }^{9}$ amely azonban igazolta a Legfelsőbb Bíróság által megfogalmazott jogi álláspont alkotmányos megfelelőségét (pontosabban fogalmazva az Alkotmánybíróság szerint nem merült fel alkotmányos összeütközés). Következtetésként elmondható, hogy ha a fogyasztó fogyasztói szerződést köt, függetlenül attól, hogy mely rendelkezésekre - különösen, ha a kereskedelmi jog rendelkezéseire - hivatkozik a szerződés, a fogyasztók jogviszonyait az SzPtk. és a fogyasztóvédelmet előíró egyéb törvények szabályozzák.

6 A fogyasztói szerződésekkel kapcsolatos joganyag átültetésének fontosságára hívja fel a figyelmet a Tt. 150/2004. sz. törvény indokolása is: "Annak érdekében, hogy az áruk magasabb minöségi követelménynek feleljenek meg, továbbá a tartós fogyasztási cikkek magasabb szinvonala érdekében a hathónapos jótállási idöt helyett két év szavatossági idöt köteles vállalni az eladó.".

7 SzPtk. 52. $\$$

8 Legfelsőbb Bíróság 3MCdo/14/2014

9 Alkotmánybíróság III.ÚS194/2016 
Problémát jelent, hogy a fogyasztási cikk (“consumer goods") fogalmának nemzeti jogba történő átültetése nem megfelelően történt meg, ugyanis a kifejezés szlovák megfelelője („tovar”) az SzPtk.-ban nem pontosan felel meg a fogyasztási cikkeknek, mivel ez a kifejezés a nemzeti jogban nem ismert jogi fogalom. Általánosan elfogadott, hogy a fogyasztási cikk fogalma alatt ingó dolgokat kell érteni, ${ }^{10}$ amelyek megfelelnek a fogyasztási cikk 1999/44/EK irányelv 1 . szakasz 2. pontjában szereplő meghatározásának.

\section{A fogyasztó meghatározása a szlovák jogban és a joggyakorlatban}

A szlovák jog több fogalmat is alkalmaz a fogyasztókra, az adott definíciót használó jogszabálytól függően. Leginkább két alapvető meghatározás található a nemzeti jogi szabályozásban. ${ }^{11} \mathrm{Az}$ SzPtk. értelmében a fogyasztó olyan természetes személy, aki önálló vállalkozásán vagy egyéb vállalkozási tevékenységén kívül jár el a szerződéskötés és a teljesítés során. ${ }^{12} \mathrm{Az}$ SzFvt. szabályozása szerint a fogyasztó olyan természetes személy, aki vállalkozási tevékenységén, foglalkozásán vagy szakmai tevékenységén kívül jár el a szerződéskötés és a teljesítés során. ${ }^{13}$

Látható, hogy a jelenleg hatályos jogi szabályozás szerint fogyasztó csak természetes személy lehet, jogi személy nem. Az egyetlen kivételt (a szerző jelenlegi tudomása szerint) a Tt. 429/2009. számú, a fizetési szolgáltatásokról és egyes törvények módosításáról szóló törvény $44 \mathrm{~d}$. \$ (5) bekezdése jelenti, amely szerint: „Minden olyan szervezetet, amely a keretszerzödés megkötésekor kevesebb, mint tiz alkalmazottat foglalkoztat, és amelynek éves árbevétele vagy eszközeinek a teljes összege nem haladja meg a 2000000 eurót, fogyasztónak minösül a fizetési számlaváltás céljából."

Korábban, de már az 1999/44/EK irányelv átültetését követően, a fogyasztó fogalma az SzPtk. és az SzFvt.-ben jelentősen eltért. Az egyik oldalon az SzPtk. a fogyasztót csakis természetes személyként határozta meg (ugyanúgy,

10 A hatályos szabályozás azonban nem definiálja sem az ingó, sem az ingatlan dolgok fogalmát. A korábbi SzPtk. - a módosított Tt. 141/1950. sz. törvény - úgy definiálta a dolgok jogi fogalmát, mint olyan birtokolható, kézzelfogható tárgy vagy természeti erőforrás, amely emberi szükségletet elégít ki (23. \$). A jogtudomány által kidolgozott elméleti fogalom (pl. J. Lazar: Občianske právo hmotné. Iura Edition, Bratislava, 2018.) a korábbi jogi szabályozással van összhangban.

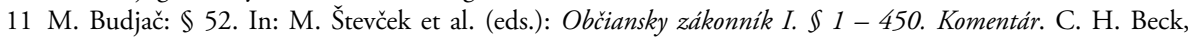
Prague, 2019, 527-530.

12 SzPtk.52. $\$(4)$ bekezdés.

13 SzFvt. 2. $\$$ a) pont. 
ahogy jelenleg is), az SzFvt. szerint azonban a fogyasztó (2014-ig) ${ }^{14}$ természetes és jogi személy is lehetett ${ }^{15}$ az alábbiak szerint: fogyasztó az a természetes vagy jogi személy, aki a dolgot vagy a szolgáltatást saját vagy családtagjai szükségleteinek kielégítése érdekében vásárolja meg vagy veszi igénybe. A korábban hatályos fogyasztóvédelmi törvény - Tt. 634/1992. sz. törvény - szerint fogyasztó azon természetes vagy jogi személy, aki üzleti/vállalkozási tevékenységén kívül eső célból vásárol dolgot vagy vesz igénybe szolgáltatást. ${ }^{16}$

Az ítélkezési gyakorlatban egy másik kérdés merült fel: lehet-e a vállalkozói pozícióban lévő természetes személy fogyasztó? A Legfelsőbb Bíróság kimondta, ${ }^{17}$ hogy lehetséges - pl. abban az esetben, ha egy ügyvéd megállapodást köt egy mobilhálózat-üzemeltetővel, és annak szolgáltatásait üzleti tevékenységén kívül is használja. A kérdésre szigorúbb választ adott az Európai Unió Bírósága a C-110/14. sz. Costea (román szabályozáson alapuló) ügyben: “A fogyasztókkal kötött szerzödésekben alkalmazott tisztességtelen feltételekröl szóló, 1993. április 5-i 93/13/ EGK tanácsi irányelv 2. cikkének b) pontját akként kell értelmezni, hogy egy olyan természetes személyt, aki ügyvéd, és aki anélkül köt egy bankkal hitelmegállapodást, hogy a szerzödés meghatározná a hitel célját, „fogyasztónak” lehet tekinteni e rendelkezés értelmében, amennyiben az emlitett szerzödés nem kötödik ezen ügyvéd szakmai tevékenységéhez. Az a körülmény, hogy az ugyanezen szerzödésböl eredö követelés fedezetéül olyan jelzálog-biztositék szolgál, amelyröl e személy ügyvédi irodájának képviselöjeként állapodott meg, és amelyet az emlitett személy szakmai tevékenységének gyakorlására szolgáló tárgyi eszközökön, például az ezen ügyvédi iroda tulajdonában lévö ingatlanon alapitottak, e tekintetben nem bir relevanciával.". ${ }^{18}$

Az ítélkezési gyakorlat azzal a kérdéssel is foglalkozott, hogy a korlátolt felelősségű társaság tagja (résztulajdonosa) tekinthető-e fogyasztónak abban az esetben, ha kezességet vállal az adós egyes kötelezettségeinek teljesítéséért. A kereskedelmi jogi szabályozás szerint, ${ }^{19}$ ha a szerződés a kereskedelmi törvény hatálya alá tartozik, a szerződést biztosító mellékkötelezettségre is a kereskedelmi törvény rendelkezéseit kell alkalmazni, feltéve, hogy e körülményről a szerződési biztosítékkal kötelezett félnek a szerződéskötéskor tudomása van, vagy ahhoz kifejezetten hozzájárult.

14 A jogi személyeket a Tt. 102/2014. sz. törvény vette ki a fogyasztóvédelem hatálya alól.

15 SzFvt. 2. $\$$ a) pont.

16 Korábbi fogyasztóvédelmi törvény $(634 / 1992) 2$. $\$$ (1) bekezdés a) pont.

17 Legfelsőbb Bíróság 1Obdo/V/9/2012.

18 C-110/14. sz. Costea ügyben 2015. szeptember 3-án hozott ítélet (ECLI:EU:C:2015:538).

19 Tt. 513/1991. sz. törvény a kereskedelmi törvénykönyvről, 262. \$. 
Ez az értelmezés ütközhet az SzPtk. fentebb idézett 52. \$-ával. A Legfelsőbb Bíróság úgy ítélte meg, ${ }^{20}$ hogy azt a természetes személyt, aki tulajdonosként vagy vezető tisztségviselőként szorosan kötődik a társasághoz (szoros kapcsolatban áll a társasággal), és kezesként vállalja a vételár megfizetését a kereskedelmi szerződésben (ahol két vállalkozás a szerződést kötő fél) nem lehet fogyasztónak tekinteni. Ezt az álláspontot a Legfelsőbb Bíróság az Európai Unió Bíróságának ítélkezési gyakorlatára támaszkodva fogalmazta meg: „A polgári és kereskedelmi ügyekben a joghatóságról, valamint a határozatok elismerésérölés végrehajtásárólszóló, 2000. december 22-i 44/2001/EK tanácsi rendelet 15. cikkének (1) bekezdését akként kell értelmezni, hogy az olyan természetes személy, aki szoros szakmai kapcsolatban áll valamely társasággal, mint annak ügyvezetöje vagy többségi tulajdonosa, nem tekinthetö e rendelkezés értelmében fogyasztónak, ha olyan kötelezvény tekintetében vállal váltókezességet, amelyet e társaság hitelnyújtásra vonatkozó szerzödés alapján fennálló kötelezettségeinek biztositása céljából állitottak ki”. ${ }^{21}$

\section{A szerződésszerüség vizsgálata és terjedelme a tagállami szabályozásban ítélkezési gyakorlatban}

Az eladó a szerződés hatálya alatt a fogyasztónak eladott dolog megfelelőségét a szerződés hatálya alatt szavatolni köteles. ${ }^{22}$ Konkrétan, az eladásra szánt dolognak meg kell felelnie a szerződésben előírt vagy a jogszabályokban meghatározott minőségi követelményeknek, egyúttal hibáktól mentesnek kell lennie, és meg kell felelnie a kötelező érvényű műszaki szabványoknak. ${ }^{23}$ Más szóval, az a személy, aki a dolgot ellenérték fejében átruházza, felelősséggel tartozik azért, hogy az (a dolog) a teljesítés időpontjában rendelkezik azokkal a tulajdonságokkal, amelyeket a felek kifejezetten meghatároztak a szerződésben, vagy amelyekkel általánosságban kell, hogy rendelkezzen, hogy azt a szerződés

20 Legfelsőbb Bíróság 5Ndc/10/2016.

21 C-419/11. sz. Česká sporitelna ügyben 2013. március 14-én hozott ítélet (ECLI:EU:C:2013:165)

22 Lásd még M. Jurčová - M. Novotná - Z. Adamová - R. Dobrovodský: Online purchase contracts and purchase of digital contents - reflections on a new regulation. Právny obzor: teoretický ćasopis pre otázky štátu a práva. 2017, Vol. 2., 145.; Lásd még R. Dobrovodský: Varstvo potrošnikov pri spletnem poslovanju Common EU rules on digital content: Future challenges for domestic legislator (Skupna pravila EU o digitalnih vsebinah: izzivi za domačega zakonodajalca). In: A. Vlahek et al (eds.): Varstvo potrošnikov pri spletnem poslovanju. IUS software, GV Založba: Inštitut za primerjalno pravo pri Pravni fakulteti, Ljubljana, 2017. 83-92.

23 SzPtk. 616. $\$$ 
jellegével és céljával összhangban lehet felhasználni, vagy amire a felek megállapodtak, továbbá jogszavatossággal is tartozik. ${ }^{24}$

A nemzeti szabályozás e kötelezettségeket több rendelkezésben is hangsúlyozza. Általánosságban, az SzPtk. 496. \$-a előírja, hogy a fogyasztói szerződések esetében a dolog tulajdonságainak, rendeltetésének és minőségének olyan természetűnek kell lennie, amely iránt a fogyasztó érdeklődést mutatott, és amely megfelel a szállító, a gyártó vagy a forgalmazó által közzétett és bármely formában, különösen a dolog vagy szolgáltatás reklámozása, népszerűsítése vagy címkézése révén hozzáférhető leírásnak. Amennyiben a dolog minőségéről kifejezetten nem állapodnak meg, azt köteles átlagos mennyiségü, és közepes minőségű dologgal teljesíteni. A fogyasztó nem köthet olyan szerződést, amelyben a hivatalosan jóváhagyott minőségű (ha van ilyen) dologtól eltérő minőségü dolgot szállítanak, mivel a vállalkozás köteles a minőségi követelményeknek megfelelő szolgáltatással teljesíteni. ${ }^{25}$ Amennyiben a minőséget a felek külön nem határozzák meg, akkor a vállalkozás minőségi követelményeknek meg nem felelő minőségű dolgot csak akkor értékesíthet, ha valamennyi minőségi eltérésre felhívta a fogyasztó figyelmét. ${ }^{26}$

Ha a dolog olyan hibában szenved, amely a rendeltetésszerü használatát nem akadályozza, csak olyan áron szabad értékesíteni, amely alacsonyabb, mint az azonos, de hibától mentes dolog ára. A fogyasztót a dolog hibájáról, valamint a hiba természetéről külön tájékoztatni kell, kivéve, ha a hiba az ügylet (értékesítés) természetéből nyilvánvalóan következik. ${ }^{27}$ Mint már említettem, a hibás terméket jogszerűen kétféleképp lehet értékesíteni, egyrészt, ha a dolog hibája az értékesítés természetéből egyértelműen következik, másrészt, ha az eladó előzetesen tájékoztatja a fogyasztót a hibákról. Abban az esetben, ha a fogyasztó egyedi mü elkészítésére köt szerződést (rendel meg), és ahhoz hibás alapanyagot szolgáltat,

24 SzPtk. 499. $\$$ Ez nem kizárólag fogyasztói jogviszonyokra alkalmazandó, hanem általános szabályoként valamennyi polgári jogviszonyra.

25 A minőségi követelmény a minőség olyan szintjét jelöli, amely biztosítja az áru valamennyi anyagjellemzőjének megtartását, amely szükséges annak azonnali használatához, és amely teljesíti a fogyasztó előrelátható elvárásait (SzFvt., 2. $\$ \mathrm{k}$ ) pont).

26 SzFvt. 4. $\$(1)$ bekezdésének b) pontja. A tárgy szempontjából kisebb jelentőséggel bír, hogy a kereskedelmi törvénykönyv 759. \$-a eltérő megközelítést alkalmazva akként rendelkezik a kereskedelmi jogviszonyok tekintetében, hogy amennyiben a szerződést kötő felek székhelye, gazdasági tevékenységének helye, vagy, amennyiben alkalmazandó, lakóhelye a Szlovák Köztársaság területén található, vagy a félnek a vállalkozása vagy fióktelepe van e területen, úgy az fogja meghatározni az áru minőségét a jogszabállyal szemben, az ilyen szabályozásnak a használhatóság elfogadható minőségére vonatkozó rendelkezései alkalmazandók a minőség meghatározása során; ez nem alkalmazható, amennyiben a szerződésből vagy a fél nyilatkozatából, illetőleg a fél üzleti tevékenységéből az következik, hogy az árut exportálni kell.

27 SzPtk. 618. \$ 
a vállalkozónak kötelessége felhívni a fogyasztó figyelmét az alapanyag hibájára (vagy a fogyasztó szakszerütlen utasításaira, ha van ilyen), ${ }^{28}$ ellenkező esetben a vállalkozó felel az utasítás végrehajtásából eredő minden olyan kárért, amely a szakszerűtlen utasítás teljesítéséből vagy a hibás anyag felhasználásából ered. A nyilvánvaló hiányosságokra vagy az illetékes földhivatal ingatlannyilvántartásból megállapítható hibákra alapítva nem lehet szavatossági igényt érvényesíteni, kivéve, ha az eladó a dolog hibátlanságát kifejezetten szavatolta. ${ }^{29}$

\section{A szavatossági és jótállási igények érvényesítése}

Az eladó felelősségét a nemzeti jogszabályok az alábbiak szerint határozzák meg: az eladó a dolog átvételét követően felel a terméknek a fogyasztónál bekövetkezett hibáiért. Használt dolgok esetén az eladó nem vállal felelösséget a dolog használatából vagy elhasználódásából eredő hibákért. Az alacsonyabb áron eladott dolgok esetében az eladó nem felel azokért a hibákért, amelyek miatt az alacsonyabb árat állapította meg. ${ }^{30}$ Konkrétan: a jogi szabályozás (az SzPtk. 622-624. \$-ai) igényérvényesítési lehetőséget biztosít a fogyasztónak a dolog hiányosságai esetén. Amennyiben a hiba kijavítható, a fogyasztónak joga van követelni a hiba ingyenes, megfelelő módon és időben történő kijavítását. Az eladó köteles a hiba kijavítására vonatkozó kötelezettségének indokolatlan késedelem nélkül eleget tenni.

A fogyasztó a hiba kijavítása helyett kérheti a dolog kicserélését, vagy ha a hiba csak a dolog egy alkatrészét érinti, akkor a hibás alkatrész cseréjét kérheti, kivéve, ha ez az eladónak aránytalan többletköltséget eredményezne, figyelembe véve a szolgáltatás hibátlan állapotban képviselt értékét, vagy a hiba nagyságát.

$\mathrm{Az}$ eladó bármikor jogosult kicserélni a hibás dolgot hibátlan tulajdonságokkal rendelkező dologra ahelyett, hogy kijavítaná a hibát, kivéve, ha ez komoly nehézségeket okoz a fogyasztó számára.

Ha a dolog olyan hibával rendelkezik, amelyet nem lehet kijavítani, és amely megakadályozza a dolog rendeltetésszerủ használatát - amelyre a dolog hibátlan állapotban egyébként alkalmas volna - a fogyasztó követelheti a dolog kicserélését vagy elállhat a szerződéstől.

28 SzPtk. 645. \$(2) bekezdés.

29 A polgári jogban a hibás teljesítésért fennálló felelősség területén alkalmazásra kerülő általános szabály. SzPtk. 500. \$ (1) bekezdés.

30 SzPtk. 619. \$ 
A fogyasztó ugyanezt követelheti, ha a hiba kijavítható, de a fogyasztó nem tudja megfelelően használni a dolgot a hiba javítás utáni megismétlődése vagy a hibák nagy száma miatt. Korábban kérdéses volt, hogy mit jelent a hiba javítás utáni megismétlődése vagy a hibák nagy száma. Az ítélkezési gyakorlat szerint a hiba megismétlődése azt jelenti, hogy ugyanaz a hiba legalább háromszor/ az első javítás után legalább kétszer fordul elő, vagy ugyanaz a kár a második javítás után megismétlődik. ${ }^{31}$ Ugyanannak a hibának kell tekinteni (egyedi esetben), ha a hiba a teljesítés során ugyanúgy nyilvánul meg. ${ }^{32} \mathrm{~A}$ „hibák nagy száma” a bíróság értelmezésében azt jelenti, hogy a dolognak egyszerre legalább 3 hibája van. ${ }^{33}$

Ha a dolognak olyan hibái vannak, amelyeket nem lehet kijavítani, a fogyasztónak joga van követelni a vételár észszerű mértékű csökkentését.

Összefoglalva: a fogyasztó követelheti:

- a hiba ingyenes, megfelelő módon és időben történő kijavítását;

- a hiba kijavítása helyett a dolog kicserélését, vagy ha a hiba csak a dolog egy alkatrészét érinti, akkor a hibás alkatrész cseréjét;

- a dolog kicserélését vagy elállhat a szerződéstől, ha a dolog olyan hibával rendelkezik, amelyet nem lehet kijavítani, és amely megakadályozza a dolog rendeltetésszerü használatát (amelyre a dolog hibátlan állapotban egyébként alkalmas volna), vagy ha a hiba kijavítható, de a fogyasztó nem tudja megfelelően használni a dolgot a hiba javítás utáni megismétlődése vagy a hibák nagy száma miatt,

- a vételár észszerü mértékű csökkentését, ha a dolognak olyan hibái vannak, amelyeket nem lehet kijavítani.

- a vételár észszerű mértékű csökkentését (a dolog kicserélése helyett) ha a csökkentett áron megvásárolt vagy használt dolog hibájáért az eladó felelős.

A szavatossági igény érvényesítésének szabályait az SzFvt. 18. \$-a tartalmazza. ${ }^{34}$ A vállalkozó megfelelő módon köteles tájékoztatni a fogyasztókat az igény benyújtásának feltételeiről és módjáról. A tájékoztatásnak ki kell terjednie az igény benyújtásának a helyére és a szavatossági javítások elvégzésének helyszínére.

31 Legfelsőbb Bíróság R 22/1983, R 2/1978

32 Legfelsőbb Bíróság 4Cdo/10/2009, Galantai (Galántai) Regionális Bíróság 20C/69/2009, Prešovi (Eperjesi) Regionális Bíróság 12C/244/2008

33 Legfelsőbb Bíróság R 22/1983, R 2/1978

34 A bírói gyakorlat is megerősítette, pl. Legfelsőbb Bíróság 8Sžo/389/2009 
A szavatossági igény érvényesítésével kapcsolatos szabályokat a fogyasztók számára hozzáférhető, jól látható helyen kell elhelyezni (általában az üzlet hirdetőtábláján). ${ }^{35} \mathrm{~A}$ vállalkozás az igényt a kezelésére kijelölt helyen, ennek hiányában bármely olyan létesítményben köteles befogadni, ahol a termékeket értékesíti vagy a szolgáltatást nyújtja. Nem alkalmazandó ez a szabály a kijavítással összefüggő igény esetén, ha a vállalkozás a kijavítás elvégzésére más személyt jelölt ki.

A nyitvatartási időben egy, a fogyasztói igények kezelésére feljogosított alkalmazottnak jelen kell lennie a létesítményben. Csoportos utazás esetén a vállalkozásnak gondoskodnia kell egy panaszkezelésre felhatalmazott alkalmazott állandó jelenlétéről, aki az utazás teljes ideje alatt jogosult kezelni a szavatossági igényeket. A vállalkozásnak, az általa kijelölt alkalmazottnak, vagy más személynek tájékoztatnia kell a fogyasztót a jogairól, a fogyasztó döntésének megfelelően, és az általa szolgáltatott információk alapján a vállalkozás köteles haladéktalanul megteremteni az igényérvényesítés feltételeit. A vállalkozás a panaszt három, bonyolult esetben legfeljebb harminc napon belül köteles megvizsgálni. Az igényérvényesítés módjának megválasztását követően azt indokolatlan késedelem nélkül, de legkésőbb az igény beérkezését követő 30 napon belül végre kell hajtani. E határidő eredménytelen elteltét követően a fogyasztónak joga van elállni a szerződéstől vagy követelni a dolog kicserélését. ${ }^{36}$ Felügyeleti szerv kérésére a vállalkozás köteles bemutatni az igény visszaigazolásának egy példányát, amely tartalmazza azokat az okokat, amelyek miatt az igény rendezésének módját nem lehet haladéktalanul eldönteni, vagy amely miatt az igényt nem lehet azonnal rendezni az igényérvényesítés módjának megválasztását követően, a kézbesítés és a szakmai értékelés eredményeit, valamint az igényérvényesítési okmány másolatát.

Szavatossági igény benyújtása esetén a vállalkozás köteles a fogyasztónak átvételi elismervényt adni. Ha az igényt elektronikus úton nyújtják be, a kereskedő köteles haladéktalanul visszaigazolást küldeni a fogyasztónak. Ha a visszaigazolást nem lehetett haladéktalanul kézbesíteni, akkor indokolatlan

35 Rövid utalás az online közzétett általános feltételekre nem elégséges, ahogy az uszoda bejáratánál kifüggesztett egy, összetüzött irat sem - Košice-i (Kassai) Járásbíróság 5S/18/2016

36 Legfelsőbb Bíróság 6MCdo/16/2011 (R 126/2014): “A panasz kezelésére nyitvaálló 30 napos határido" leteltét követöen a fogyasztó jogosult elállni a szerzödéstöl vagy kérni a dolog kicserélését egy újra. Azonban a fogyasztó továbbra is jogosult kérni a dolog kijavitását. Amennyiben a fogyasztó kiválasztja a jogorvoslat módját, attól nem térhet el. Ha a vállalkozás nem tesz eleget a fogyasztó kérésének, a fogyasztó igényét a biróság elött érvényesitheti, azonban annak csak olyan módját választhatja, amelyet a vállalkozással szemben megkisérelt érvényesiteni." 
késedelem nélkül, de legkésőbb az igényérvényesítési dokumentációval együtt azt kézbesíteni kell. Nem kell visszaigazolni az igény benyújtását, ha a fogyasztónak lehetősége van az igény benyújtását más módon bizonyítani. A vállalkozás az igény benyújtását követő 30 napon belül köteles írásban kiállítani az igény rendezéséről szóló dokumentációt. ${ }^{37} \mathrm{~A}$ vállalkozás köteles a szavatossági igények ről nyilvántartást vezetni, és a felügyeleti hatóság felhívását követően azt áttekintésre átadni. A szavatossági igények nyilvántartásának tartalmaznia kell a szavatossági igény benyújtásának dátumát, a kezelés dátumát és módját, az igény sorszámát. Indokolt esetben a szavatossági igény a vállalkozás által kijelölt személy által, helyen vagy szervezet útján is kezelhető. A szavatossági igény a szavatossági idő lejártát nem érinti. A kártérítéshez való jogot a szavatossági igény szintén nem befolyásolja.

Nincs kötelező szabályozás alkatrészek készleten tartására.

Annak bizonyítása, hogy a hiba valóban bekövetkezett vagy hogy a dolog hibás-e, a jogi szabályozás nem ad megfelelő eligazítást, ezért annak feltételeit a bírói gyakorlat munkálta ki:

- abban az esetben, ha a fogyasztó a dolog meghibásodása miatt két alkalommal érvényesít szavatossági igényt, és a szakértő előtti tesztelés során hiba egyik alkalommal sem jelentkezik, akkor a fogyasztó nem állhat el a szerződéstől, ${ }^{38}$

- az igény kezelésére biztosított 30 napos határidő lejárta nem jelenti a hiba fennállásának vélelmét és a fogyasztói igény elismerését. Szükséges, hogy a hiba valóban fennálljon. A fogyasztó által érvényesített szavatossági igény csak akkor indokolt, ha a hiba valóságos, a hiba a szavatossági időn belül jelentkezik, a hiba jellege a törvény által elfogadható (ez azt jelenti, hogy nem a dolog nem megfelelö/ rendeltetésellenes használatából ered). ${ }^{39}$

37 Az eladó e kötelezettsége kizárólag a fogyasztó részére történö kiadásként, nem pedig szállitásként értelmezendő. Legfelsőbb Bíróság 8Asan/13/2018, 10Sžo/188/2015

38 Prešovi Regionális Bíróság 12C/244/2008

39 Legfelsőbb Bíróság 3Cdo/220/2017 (R 28/2019). Az idézett bírósági döntést széles körben tartják jogilag tévesnek, mert (föként) az SzFvt. 18. \$(4) bekezdését: “...A panasz kezelés módjának kiválasztását követöen azt haladéktalanul, de legkésöbb a panasz kézhezvételét követö 30 napon belül ki kell vizsgálni. E határidö elteltét követöen a fogyasztó jogosult a szerzödéstöl elállni vagy a hibás dolog kicserélését kérni egy újra." contra legem módon értelmezi. Az idézett rendelkezés szerint a fogyasztó csak akkor jogosult a szerződéstől elállni, ha a panasza nem kerül kivizsgálásra a határidőn belül - tehát az elállási jog egyfajta szankció a vállalkozással szemben a panasz határidőben történő kivizsgálásának elmulasztásáért, azonban a Legfelsőbb Bíróság szerint egyéb feltételeknek is fenn kell állnia. Véleményünk szerint ez a jogszabály szövegének félreértelmezése, amely a fogyasztói jogok érvényesítésének akadályozását eredményezi. Kritikát fogalmazott meg a jogtudósok széles köre, pl. T. Čentík: K následkom nevčasného vybavenia spotrebitel'skej reklamácie. Ulpianus interkatívne právnické komentáre. 2018, elérhető: https://www.ulpianus.sk/judikatura-s-komentarom/k-nasledkom- 


\section{A szavatossági és jótállási igények érvényesítésére nyitva álló határidő határidejét a szlovák jogban}

A szlovák jog szerint (elsősorban az SzPtk. 619-627. §-ai alapján) a szavatossági/ jótállási időre külön szabályok vonatkoznak (mindegyik meghosszabbítható, de egyiket sem lehet lerövidíteni):

- az eladott dologra (a fogyasztók számára) a szavatosság huszonnégy hónap [SzPtk. 620. \$(1) bekezdés]. Ha az eladott dolgon, annak csomagolásán vagy használati útmutatóján a dolog felhasználhatóságának határideje feltüntetésre kerül, a szavatossági idő az ilyen határidő lejártakor nem jár le,

- használt dolgok (fogyasztó részére történő értékesítése) esetén a fogyasztó és az eladó megállapodhatnak egy rövidebb, de legalább tizenkét hónapos szavatossági időben is [SzPtk. 620. $\$$ (2) bekezdése],

- egyedi mű (megrendelésre készített dolog) elkészítése esetén a szavatossági idő huszonnégy hónap [SzPtk. 646. \$ (1) bekezdése],

- a dolog javítására vagy átalakítására vonatkozó szavatossági idő három hónapig tart, hacsak a felek megállapodása vagy a jogszabály eltérően nem rendelkezik; az építési munkákra vonatkozó szavatossági idő legalább tizennyolc hónap (SzPtk. 654. \$). ${ }^{40}$

A szavatossági idő a dolog fogyasztó általi átvételétől kezdődik. Ha a vásárolt dolgot az eladótól eltérő vállalkozó fogja üzembe helyezni, a szavatossági idő a dolog üzembe helyezésének napjától kezdődik, feltéve, hogy a fogyasztó az üzembe helyezést legkésőbb a dolog átvételétől számított három héten belül kéri, és az ahhoz szükséges időt és együttmüködést tanúsítja.

A szavatosság vállalása nem kötött írásbeli nyilatkozathoz, de ha a fogyasztó kéri, az eladó köteles írásban igazolni annak tényét (szavatossági nyilatkozat). Ha a dolog jellege megengedi, elegendő szavatossági igazolás helyett az értékesítés tényét igazolni.

Az eladó a fogyasztó számára kiadott szavatossági nyilatkozatban vagy hirdetésben a törvényben előírt szavatossági időnél hosszabb szavatosságot is vállalhat. Az eladó a szavatossági nyilatkozatban a szavatosság feltételeit és hatályát feltünteti.

\footnotetext{
nevcasneho-vybavenia-spotrebitelskej-reklamaciel (letöltés dátuma: 2020.03.01.)

40 Épület felépítése esetén a szavatossági idő három év [SzPtk. 646. § (3) bekezdés].
} 
A szavatossági jogokat azzal az eladóval szemben kell gyakorolni, akitől a dolgot megvásárolták. Ha a szavatossági nyilatkozatban a kijavítás elvégzésére egy olyan másik vállalkozót jelöltek meg, aki azon a településen működik, ahol az eladó, vagy a fogyasztóhoz közelebb található, a kijavítás iránti igény a javításra kijelölt vállalkozónál érvényesíthető. A javítást az elvégzésére kijelölt vállalkozónak az eladó és a fogyasztó közötti, a dolog eladása során kötött megállapodásban megállapított határidőn belül kell elvégeznie.

A szavatossági idő alatt a dologban bekövetkezett hibákért való felelősség megszűnik, ha a hibás teljesítésből eredő igényeket a szavatossági idő alatt nem gyakorolják. A bizonyítási teherre nincs kifejezett szabályozás, azonban vélelem alapján az eladó felel a szavatossági idő alatt bekövetkezett olyan hibákért, amelyek a dolog fogyasztó általi átvételét követően keletkeztek (szavatosság).

A gyorsan romlandó dolgokban bekövetkezett hibákért való felelősséggel járó igényt legkésőbb a vásárlást követő napon kell érvényesíteni, ennek elmulasztása esetén a szavatossági jog elvész.

Használt dolgok esetén a hibákért való felelősségből eredő igény elvész, ha azt a fogyasztó a dolog átvételét követő huszonnégy hónapon belül, vagy az eladóval a jogszabály alapján megkötött megállapodásukban megállapított hosszabb határidőn belül nem érvényesíti.

A szavatosság idejébe a hibás teljesítésért való felelősséggel kapcsolatos igény érvényesítésétől a dolognak a kijavítás befejezését követő átvételéig tartó időszak nem számít bele. Az eladó köteles a fogyasztónak igazolást kiállítani a jog gyakorlásának napjáról, a javításról és a javítás időtartamáról.

A dolog cseréje esetén a szavatossági idő az új dolog átvételétől újrakezdődik. Ugyanez vonatkozik a szavatossági igény érvényesítése miatt kicserélt alkatrészre is.

\section{A jótállás érvényesítésének különös szabályai}

A jótállási idő két részre oszlik - a vásárlástól számított 12 hónapig, és a 12 hónap elteltét követően a vásárlástól számított 24 hónap végéig.

Ha a fogyasztó a dologgal kapcsolatban a vásárlást követő 12 hónapon belül jótállási igényt érvényesít, akkor a vállalkozás azt kizárólag a saját költségén elvégzett szakmai értékelés (szakvélemény) alapján utasíthatja el, amellyel a fogyasztónak nem okozhat járulékos költséget. A vállalkozás legkésőbb az igény benyújtását követő 14 napon belül köteles átadni a szakmai értékelés egy példányát a panasz elutasításának indokaival. A panasz elutasítása a bírósághoz fordulás jogát nem érinti. 
A fogyasztók jogai és az eladó kötelezettségei az igényérvényesítés idejétől függően különböznek. Ha a fogyasztó a dologgal kapcsolatos igényét 12 hónapon túl, de még a vásárlástól számított 24 hónapon belül érvényesíti a vállalkozással szemben, a vállalkozás azt kizárólag a saját költségén elvégzett szakmai értékelés (szakvélemény) alapján utasíthatja el. A szakvélemény elkészítése - függetlenül annak megalapozottságától - nem okozhat járulékos költséget a fogyasztónak. Az igény ismételten érvényesíthető, ha a fogyasztó szakvélemény alapján bizonyítja a vállalkozás felelősségét. A szakvélemény elkészítésének ideje alatt a jótállási idő nyugszik. A vállalkozás köteles megtéríteni a fogyasztónak minden, a szakvélemény elkészítésével kapcsolatban felmerült költségét és egyéb kárát. Ha az igényt ugyanazon hiba miatt ismételten érvényesítik, azt nem lehet elutasítani. ${ }^{41}$

\section{A fogyasztó egyéb igényérvényesítési lehetőségei a szavatosságon és a jótálláson túl}

A tisztességtelen kereskedelmi gyakorlat vagy tisztességtelen szerződési feltétel alkalmazásából eredő igényt kivéve azáltalánosszabályokalkalmazandók (elállási jog, felelősség a szerződés érvénytelenségéért vagy a kárért). Hangsúlyozni kell, hogy Szlovákiában a fogyasztóvédelemre külön intézmény működik (de csak ritkán alkalmazandó, bíróság előtti fogyasztói igény érvényesítésekor) ${ }^{42} \mathrm{Az}$ SzFvt. értelmében „Az a személy, aki sikeresen igazolja az e törvényben és külön rendeletekben meghatározott jog vagy kötelezettség megsértését, megfelelö pénzbeli kártéritést követelhet attól a személytöl, aki az e törvényben vagy egyéb rendeletben meghatározott jog vagy kötelezettség megsértésével a fogyasztónak kárt okozott."43

\section{A fogyasztói igényé érvényesítése a vállalkozással szemben}

Általánosan elfogadott elv (nincs jogszabály által kötelezően előírva), hogy a fogyasztónak először az eladóval (vállalkozással) szemben kell igényét érvényesíteni, és csak utána fordulhat bírósághoz. ${ }^{44,45}$

41 A rendelkezés az SzFvt. 18. $\$(6)-(7)$ bekezdéseiben található.

42 Žilina-i (Zsolnai) Járásbíróság 3Co/20/2017, Pozsonyi Járásbíróság 21Co/69/2018 22Co/40/2019 21Co/168/2016

43 SzFvt. 3. $\$(5)$ bekezdés.

44 Véleményünk szerint a fogyasztó közvetlenül a bírósághoz fordulhatna, ez azonban nagyobb kockázattal járna a törvényi szabályozás hiányában és az eltérő bírói megközelítés miatt.

45 Ezt a megközelítést igazolja az elévülési idő kérdése - Azon jogok esetében, melyeket elsődlegesen természetes személlyel vagy jogi személlyel szemben kell gyakorolni, az elévülési idő azon a napon kezdődik, amikor a jogosult jogát ennek megfelelően gyakorolja. (SzPtk. 102. \$.) 
A fogyasztónak az igényérvényesítés során fokozott körültekintéssel kell eljárnia, mivel az érvényesíteni kívánt igénynek összhangban kell állnia a bírósághoz benyújtott keresettel. Az igény kezelésére nyitva álló 30 nap elteltét követően a fogyasztónak joga van elállni vagy kérni a dolog kicserélését. Ettől függetlenül továbbra is követelheti a dolog kijavítását. Ha a fogyasztó kiválasztotta az igényérvényesítés módját, attól később nem térhet el. Ha a vállalkozás nem tartja tiszteletben a fogyasztó jogait, a fogyasztó keresetet nyújthat be a bírósághoz, de a fogyasztó csak a vállalkozás előtt érvényesíteni megkísérelt igényét kértheti a bíróságtól. ${ }^{46}$

A dolog hibája következtében okozott károk érvényesítésére a hibás termékekkel kapcsolatos felelősség speciális szabályai irányadók. ${ }^{47}$ Károkozás esetén az SzPtk. általános szabályait kell alkalmazni.

A fogyasztó megkeresheti az országos hatóságot - a Szlovák Kereskedelmi Felügyeletet, hogy a vállalkozás működése felett felügyeleti eljárást kezdeményezzen. A Szlovák Kereskedelmi Felügyelet azonban nem léphet be a fogyasztó és a kereskedő közötti jogviszonyba, a fogyasztó jogait a kereskedővel szemben nem jogosult érvényesíteni. A fogyasztó alternatív vitarendezés keretében is érvényesítheti igényét. ${ }^{48}$

Szlovákiában a tömeges kártérítés iránti keresetek továbbra sem képezik a jogi szabályozás részét. ${ }^{49,50}$

46 Legfelsőbb Bíróság 6MCdo/16/2011 (R 126/2014)

47 A Tanács 1985. július 25-i, a hibás termékekért való felelősségre vonatkozó tagállami törvényi, rendeleti és közigazgatási rendelkezések közelítéséről szóló 85/374/EGK irányelve átültetése érdekében módosított Tt. 294/1999. sz. törvény a hibás termékekért fennálló felelösségről.

48 Az SzFvt. és az alternatív fogyasztói vitarendezésről és egyes törvények módosításról szóló Tt. 391/2015. sz. törvény ültette át az Európai Parlament és a Tanács 2013/11/EU 2013. május 21-i, a fogyasztói jogviták alternatív rendezéséről, valamint a 2006/2004/EK rendelet és a 2009/22/EK irányelv módosításáról szóló irányelvet (fogyasztói alternatív vitarendezési irányelv).

49 Lásd még M. Maslák: Kolektívne záujmy spotrebitelov. In: M. Lenhart et al (eds.): Bratislava Legal Forum 2016. Collective Redress. Univerzita Komenského v Bratislave, Právnická fakulta, Bratislava, 2016, 5563., elérhető: https://www.flaw.uniba.sk/flleadmin/praflVeda/Konferencie_a_podujatialbpf_2016/Zbornik_ BPF2016_sekcia_07.pdf

50 Az SzPtk. angol fordításának forrása: Preložená legislatíva. Wolters Kluwer, IURA Edition, elérhető: http:// trleg.aspi.sk/ 
FogYASZTÓI ADÁSVÉTEL EGYES KÉRDÉSEI - SZLOVÁKIA

\section{Forrásjegyzék}

1. M. Budjač: $\$ 52$. In: M. Števček et al. (eds.): Občiansky zákonník I. $\$ 1-450$. Komentár. C. H. Beck, Prague, 2019, 527-530.

2. T. ČENTíK: K následkom nevčasného vybavenia spotrebitel’skej reklamácie. Ulpianus interkatívne právnické komentáre. 2018, elérhető: https://www. ulpianus.sk/judikatura-s-komentarom/k-nasledkom-nevcasneho-vybaveniaspotrebitelskej-reklamacie/ (letöltés dátuma: 2020.03.11.)

3. R. DoвrovodskÝ: LegislativeZersplitterung des slowakischen Verbraucherrechts. In: M. Novotná (ed.): Zásady európskeho súkromného práva v aplikačnej praxi. Spotrebitelský kódex: áno či nie? Leges, Praha, 2018, 111-139.

4. R. Dobrovodský: Der Einfluss des europäischen Verbraucherrechts auf das slowakische Schuldrecht. In: W. Rudolf (ed.): Der Einfluss des EU-Rechts in den Jahren 2007-2017 auf die Privatrechtsordnungen der CEE-Staaten. MANZ Verlag, Wien, 2019. 89-100.

5. R. Dobrovodský: Rechtsschutz des Verbrauchers (Eigentümers) vor Folgen der Liberalisierungs- und Deregulierungsschritte. Erfahrungsbericht aus der Slowakei. In: T. Zarandia et al (eds.): Eigentum und Rechtssicherheit: Wandel des Eigentumsbegriffs. Staatliche Ivane-Javakhishvili-Universität, Tbilisi, 2016. 150-165.

6. R. Dobrovodský: Varstvo potrošnikov pri spletnem poslovanju Common EU rules on digital content: Future challenges for domestic legislator (Skupna pravila EU o digitalnih vsebinah: izzivi za domačega zakonodajalca). In: A. Vlahek et al (eds.): Varstvo potrošnikov pri spletnem poslovanju. IUS software, GV Založba: Inštitut za primerjalno pravo pri Pravni fakulteti, Ljubljana, 2017. 83-92.

7. J. Lazar: Občianske právo hmotné. Iura Edition, Bratislava, 2018.

8. M. Jurčová - M. Novotná - Z. Adamová - R. Dobrovodský: Online purchase contracts and purchase of digital contents - reflections on a new regulation. Právny obzor: teoretický časopis pre otázky štátu a práva. 2017, Vol. 2., 143-161.

9. M. Maslák: Kolektívne záujmy spotrebitelov. In: M. Lenhart et al (eds.): Bratislava Legal Forum 2016. Collective Redress. Univerzita Komenského v Bratislave, Právnická fakulta, Bratislava, 2016, 55-63., elérhető: https:// www.flaw.uniba.sk/fileadmin/praf/Veda/Konferencie_a_podujatialbpf_2016/ Zbornik_BPF2016_sekcia_07.pdf(letöltés dátuma: 2020.03.11.) 
10. Az Európai Parlament és a Tanács 1999/44/EK irányelve (1999. május 25.) a fogyasztási cikkek adásvételének és a kapcsolódó jótállásnak egyes vonatkozásairól, HL L 171., 1999.7.7., 12-16.

11. Az Európai Parlament és a Tanács 2013/11/EU irányelve (2013. május 21.) a fogyasztói jogviták alternatív rendezéséről, valamint a 2006/2004/ EK rendelet és a 2009/22/EK irányelv módosításáról, HL L 165., 2013.6.18., 63-79.

12. Tt. 141/1950. sz. törvény a Polgári Törvénykönyvről

13. Tt. 40/1964. sz. törvény a Polgári Törvénykönyvről

14. Tt. 513/1991. sz. törvény a kereskedelmi törvénykönyvről

15. Tt. 634/1992. sz. törvény a fogyasztóvédelemről

16. Tt. 294/1999. sz. törvény a hibás termékekért fennálló felelősségről

17. Tt. 150/2004. törvény a Polgári Törvénykönyvről szóló Tt. 40/1964. sz. törvény módosításáról

18. Tt. 250/2007 sz. törvény a fogyasztóvédelemről

19. Tt. 429/2009. sz. törvény a fizetési szolgáltatásokról és egyes törvények módosításáról

20. Tt. 102/2014. sz. törvény a termékek és szolgáltatások távollevők közötti és üzlethelyiségen kívüli értékesítéséről

21. Tt. 391/2015. sz. törvény az alternatív fogyasztói vitarendezésről és egyes törvények módosításról

22. Európai Unió Bírósága C-419/11. sz. Česká spořitelna ügyben 2013. március 14-én hozott ítélete (ECLI:EU:C:2013:165)

23. Európai Unió Bírósága C-110/14. sz. Costea ügyben 2015. szeptember 3-án hozott ítélete (ECLI:EU:C:2015:538)

24. Legfelsőbb Bíróság R 2/1978. sz. ítélete

25. Legfelsőbb Bíróság R 22/1983. sz. ítélete

26. Legfelsőbb Bíróság $4 \mathrm{Cdo} / 10 / 2009$. sz. ítélete

27. Legfelsőbb Bíróság 8Sžo/389/2009. sz. ítélete

28. Legfelsőbb Bíróság $6 \mathrm{MCdo} / 16 / 2011$. sz. ítélete

29. Legfelsőbb Bíróság 10Sžo/188/2015. sz. ítélete

30. Legfelsőbb Bíróság $5 \mathrm{Ndc} / 10 / 2016$ sz. ítélete

31. Legfelsőbb Bíróság 3Cdo/220/2017. sz. ítélete

32. Legfelsőbb Bíróság 8Asan/13/2018. sz. ítélete

33. Prešovi (Eperjesi) Regionális Bíróság 12C/244/2008. sz. ítélete 
FogYASZTói ADÁSVÉTEL EGYES KÉRDÉSEI - SZLOVÁKIA

34. Galantai (Galántai) Regionális Bíróság 20C/69/2009. sz. ítélete 35. Pozsonyi Járásbíróság 21Co/69/2018 22Co/40/2019 21Co/168/2016. sz. ítélete

36. Žilina-i (Zsolnai) Járásbíróság 3Co/20/2017. sz. ítélete

37. Preložená legislatíva. Wolters Kluwer, IURA Edition, elérhető: http:// trleg.aspi.skl 
Dr. Peter Mészáros, PhD., 2010-ben szerezte meg jogi diplomáját a szlovák Nagyszombati (Trnava-i) Egyetem Jogi Karán, majd ugyanott PhD fokozatot szerzett 2014-ben. Jelenleg adjunktusként dolgozik az intézményben. Több, a fogyasztóvédelmi, polgári és kereskedelmi jog kérdéseivel foglalkozó folyóirat, kiadvány (társ)szerzője, ezen felül nemzeti és nemzetközi (uniós) kutatásokban is részt vesz. Polgári anyagi- és eljárásjogot, kereskedelmi-, családi-, és fogyasztóvédelmi jogot oktat. 2010 óta a Szlovák Ügyvédi Kamara tagja, szakterülete a magánjog, amely jogterületen ügyfelei bíróság előtti jogi képviseletét is ellátja. 